\title{
"A moral being is an accountable being": Adam Smith and the Ethical Foundations of Accountable Governance
}

\author{
Melvin J. Dubnick \\ University of New Hampshire \\ mdubnick@dubnick.net \\ http://mjdubnick.dubnick.net
}

Please do not cite without expressed permission of the author

Presented at the $68^{\text {th }}$ Annual Meeting of the Midwest Political Science Association, The Palmer House, Chicago IL, May 22-25, 2010 


\section{"A moral being is an accountable being": Adam Smith and Ethical Foundations of Accountable Governance Melvin J. Dubnick \\ University of New Hampshire}

\section{The Underestimation of Adam Smith}

"While some men are born small and some achieve smallness, it is clear that Adam Smith has had much smallness thrust upon him." -- Amartya Sen, 2010, p.[5]

There are certain concepts and phrases popularly associated with Adam Smith: capitalism, laissez-faire, "invisible hand," "impartial spectator," etc. Attributions of these concepts or ideas to Smith often range from the imagined to the exaggerated, even among scholars (including one or two of the Nobel-ity) who should perhaps know better. ${ }^{1}$ Among the pantheon of Enlightenment thinkers, Smith's work has become legendary in the mythical sense, the very mention of his name having become symbolically synonymous with the transformation of Western economies from mercantilism to modern capitalism. ${ }^{2}$

For a variety of disparate reasons, interest in the "real" contributions of Adam Smith [his "lost legacy," in the words of Evensky (2001) and Kennedy (2005)] has increased substantially in recent years. There has been a long-standing interest in Smith's "other" writings (that is, not the Wealth of Nations - hereafter WN) among philosophers associated with the University of Glasgow, which has laid claim as the home institution for both Smith's oeuvre and a good deal of Smith-focused scholarship. Their scholarly efforts to bring together the definitive collection of Smith's works has been welcome and supported since at least the 1970s by those who (incorrectly, as it turns out; again, see Kennedy 2005) believed it to be in their (neo-liberal) ideological interest to promote the further study of Smith's work. Complementing this has been the contemporary fascination with anniversaries, such as the bicentennial of the publication of WN (see Racktenwald 1978) and, more recently, the commemorations of the 1759 publication of The Theory of Moral Sentiments (hereafter TMS).

See the general critique of references to Smith's work in Kennedy 2005 It would seem that the only historical honor not bestowed on him was having his name attached to some -ism, e.g., Marxism, Keynesianism, Fordism. Unfortunately for Smith, his surname is now more associated with anonymity than capitalism, so that in today's popular culture a "smithism" is used to designate a real quotation not deemed worthy of attribution. 
The legendary and distorted popular view of Smith (primarily as creator and advocate for "laissez-faire capitalism") was the product of the enthusiastic and myopic search for an intellectual champion of $19^{\text {th }}$ and early $20^{\text {th }}$ century industrialization. ${ }^{3}$ Certain quotes from WN (e.g., "invisible hand" and the famous characterization of what motivates butchers, brewers and bakers), taken out of context and radically altered into so-called economic theories, became the primary basis for an understanding of his contributions to modern intellectual life. In addition, his reputation as a moral philosopher suffered as the originality of his ideas was brought into question ${ }^{4}$ and he was increasingly perceived as just another commentator who offered minor variations on the more significant work of others, especially his friend David Hume. ${ }^{5}$ Even the respect he received from notable scholars as an economic theorist was qualified. In a preface to his Principles of Political Economy, for example, John Stuart Mill honored Smith as an insightful observer of his unique times, but Mill saw little of relevance for his own time and considered the economics of WN to lack enduring value. ${ }^{6}$ With relatively superficial interpretations of WN so pervasive by the early 1900s, those few who did pay attention to $\mathrm{TMS}^{7}$ (especially in Germany) found its emphasis on benevolence sufficiently different that they initiated a thread of scholarship focused on what become known as the "Adam Smith problem" (i.e., how to explain the fact that two such different works emanated from one individual)(see Dickey 1986).

This all began to change in the last several decades. The closer reading of Smith's work that followed the initial publication of the Glasgow volumes has made clear that he was engaged in more than articulating, elaborating or extending the moral theory of others. "Smith was neither Hume, Hutcheson, or Mandeville, nor was he Newton, Pufendorf, or Quesnay. He was mentally independent, nobody's pupil, no epigone" (Recktenwald 1978, p. 74). This growing appreciation of Smith as a major Enlightenment figure (see Griswold 1999) has, in turn, drawn the attention intellectual historians (e.g., Rothschild 2001) and economic theorists (e.g., Sen 2009) who now regard Smith as a key figure in establishing one of two major perspectives on the role of reason to emerge out of the Enlightenment.

For an overview of how Smith's work has been treated, see Brown 1997.

$4 \quad$ E.g., despite his admiration for and use of Smith's work in his own theories (see Sweezey 1942), Marx mistakenly attributed some key ideas that Smith used in WN to Adam Ferguson and thought Ferguson to be Smith's intellectual mentor. In fact, Ferguson was one of a number of Smith's students who derived many of their ideas from their teacher's well-known lectures.

As Samuelson (1977) noted, Smith's work was often considered to reflect a "fuzzy eclecticism" (p. 42).

6

See p. 5 of Mill's Preface to his Principles of Political Economy (Mill 1909). In writing of his education in economics, Mill notes that he regarded Smith's analyses as superficial and, along with his father (and teacher) James, perceived it as less significant than that of the "superior" work of David Ricardo. Nevertheless, when planning to write his Principles of Political Economy, Mill used WN as his model. See Ashley's "Introduction" to the Principles, 1.1, 1.23

See Macfie 1961 on the lack of attention given to TMS. 
For Sen, whose recent work focuses on the social justice (2009), Smith stands as "perhaps the principal analyst" in a line of Enlightenment figures who assumed a "comparative" approach to determining how justice was achieved in different societies - a perspective that Sen contrasts with "contractarian" thinkers (Hobbes, Locke, Rousseau, Kant - with Rawls as the major contemporary figure) who concentrated on determining those institutional conditions would foster the attainment of some transcendent and perfect form of justice (Sen 2009, 2010; cf Nussbaum 2006). In this regard, Smith's "lost legacy" is far more substantial than a distinctive moral philosophy (Kennedy 2005), precursor to dialogical ethics (Brown 1994), or and early theorist of civil society (Evensky 2005), and is on par with the likes of Hobbes, Kant or even his friend Hume.

In this paper I will argue that Smith has still another lost legacy - that of the first modern theorist of accountable governance. I will elaborate on my rationale for that claim after reviewing the particular writings in Smith's principal work (in this case TMS rather than WN) which I believe establish his foundational role in such a theory and discussing the factors behind its "lost" status.

\section{The Lost Premise}

"A moral being is an accountable being." - TMS, 1759

Much has been written about Smith and his writings, but few have focused on the obscure seven-word epigraph heading this section. I come to the Smith literature late, drawn to it by a reference to that sentence in a philosophical by Stephen Darwall (2006, p. 101; see also Darwall 1999, p. 163). ${ }^{8}$ After two years of seeking some authoritative exegesis for the ideas expressed in that sentence and accompanying text, what I found was commentary effectively dismissing the sentence as merely a stylistic expression that lacked significance, thus accounting for its disappearance through the Smith's relatively frequent tinkering with the text for each edition. ${ }^{9}$

Not fully persuaded, I found the obscurity of the sentence is a story in itself. It is the case that those exact words appear only in the text of the first (1759) edition of The Theory of Moral Sentiments (TMS), and that they do not appear at all (even in revised form) in the $6^{\text {th }}$ edition of 1790 (which has become THE cited, definitive version of TMS used in almost all scholarship related to Smith's moral philosophy).

\footnotetext{
$8 \quad$ My reading of Darwall (2006) was prompted by his views on the accountable nature of morality.

$9 \quad$ There was one notable exception in a 1986 article by Dickey. He used the textual changes associated with the portions of TMS related that statement to support his view that there was a substantial difference in attitude and tone between the younger Smith of 1759 and the revising author of TMS's last edition three decades later. More on that point below.
} 
The differences among the editions, it turns out, is more than superficial. ${ }^{10}$ Fortunately, the editors of the definitive $6^{\text {th }}$ edition (part of the Glasgow project) provide detailed notes indicating the textual differences between editions, and (thanks to the Google book project) downloadable scans of several of the editions (including the important first and second editions) can be found online.

The "sentence" in question is found in Part III, chapter 1 of the 1759 (1st) edition as follows:

A moral being is an accountable being. An accountable being, as the word expresses, is a being that must give an account of its actions to some other, and that consequently must regulate them according to the good-liking of this other. Man is accountable to God and his fellow creatures. But tho' he is, no doubt, principally accountable to God, in the order of time, he must necessarily conceive himself as accountable to his fellow creatures, before he can form any idea of the Deity, or of the rules by which that Divine Being will judge of his conduct. A child surely conceives itself as accountable to its parents, and is elevated or cast down by the thought of their merited approbation or disapprobation, long before it forms any idea of its accountableness to the Deity, or of the rules by which that Divine Being will judge of its conduct.

Among Smith scholars there is a consensus that, of the five subsequent editions that Smith worked on, only two - the 2nd and the 6th - involved major textual revisions. As it turns out, this is particularly true for the "moral/accountable being" sentence.

In the second edition, published in 1761, Smith both modifies the sentence and moves the containing paragraph (along with two others) by inserting material that was intended (in his words) "both to confirm my Doctrine that our judgements concerning our own conduct have always a reference to the sentiments of some other being, and to shew that, notwithstanding this, real magnanimity and conscious

See Raphael 2007, pp. 1-6, for examples of Smith scholarship that either overlook or take into account the differences among the various editions. As a case study in the importance of precise citations, I found some examples of authors who referenced TMS as the 1759 edition when, upon closer examination, it turns out they were citing the 1790 edition. For a clear example, see Wilson 1993. This oversight is understandable, We work in a era where the issuance of a "new edition" of popular works is merely a means for justifying the marketability (e.g., a "new" paperback edition) or extending the copyright life of a book. The term "revised edition" more often refers to "updates" or the inclusion of a postscript or new introduction to a critically important publication (e.g. compare Simon 1947 and Simon 1957), but rarely does one assume that the author has made such significant changes that citing an earlier edition as a source would make a major difference. The norm today would be for such substantial changes to trigger publication of an entirely new book (e.g., compare Wildavsky 1979 with Wildavsky 1988). In the Wilson case, I would argue that working from earlier editions of TMS would in fact have enhanced the argument of The Moral Sense. 
virtue can support itselfe under the disapprobation of all mankind". ${ }^{11}$ The sentence now read: "Man is considered as a moral, because he is regarded as an accountable being" (TMS, $2^{\text {nd }}$ edition, Part III, Ch. 1). In short, Smith remains committed to the idea that accountability to others is the very essence of morality - and vice versa. In form and tone, however, the relationship between morality and accountability shifts from an assertion in the $1^{\text {st }}$ edition to somewhat of a hypothesis in the 2 nd as he endeavors to "confirm my Doctrine."

Those initial $2^{\text {nd }}$ edition changes generally held through editions 3 through 5 , and it was only in the $6^{\text {th }}$ edition that that specific and explicit references to the "moral/accountable being" connection disappear from the text (see the following section). In fact, the word "accountable" (in the sense of "being accountable to") is nowhere to be found in the $6^{\text {th }}$ edition, an indication that this change was more than a mere stylistic decision on the part of the author.

There are a number of different explanations for this major revision offered by Smith scholars when they do address it. On a strictly philosophical level, the changes in the $6^{\text {th }}$ edition indicate that Smith's evident appreciation for Stoic "self-command" had deepened, and that it dominated most of the additions he made to TMS in $1790 .{ }^{12}$ Others regard the $6^{\text {th }}$ edition as the product of a more conservative (Tory) Smith whose earlier work and biography clearly fit under the Whig banner. In this regard, Dickey (1986) sees in the $6^{\text {th }}$ edition the emergence of a more skeptical Smith whose observations of human behavior over several decades lead him to a less sanguine view on human nature.

Still others see the changes in the $6^{\text {th }}$ edition as a reflection of Smith's growing anxiety for the safety and reputation of those former students and other associates whose future might be tainted by their association with Smith's views (and former association with French intellectuals whose work formed the basis for the French Revolution). Although difficult to imagine in a day and age when Smith is often identified with the neo-liberal and libertarian right, at the time of the French uprising his ideas could be - and probably were - read as support for the Revolution by the ruling elite of Great Britain (Rothschild 1992). At the time of the Revolution, certain words - what Raymond Williams would later call "keywords" -- were particularly sensitive in political discourse, and while the cries for "liberté, égalité, fraternité" inspired many to action, they also struck fear in some influential circles in the United Kingdom. Although not of the status of those three terms, the idea of "accountability" to the people (or,

\footnotetext{
11 From letter to Gilbert Elliott, 10 October 1759, discussing changes to be made in the $2^{\text {nd }}$ edition of TMS; Smith, Mossner \& Ross 1987, p. 49.

12 See Seigel 2005, pp. 139-140 for a discussion of Smith's view of Stoicism.
} 
as some would read it, the mob) was among the words that might be misconstrued and result not merely in open criticism, but in bodily harm. ${ }^{13}$

Whatever the reason for his abandonment of the explicit connection between morality and accountability, the link is retained implicitly in the $6^{\text {th }}$ edition. Consider the following paragraphs from the $6^{\text {th }}$ that are found in reasonable proximity to the location of those addressing the connection in earlier editions:

... To a man who from his birth was a stranger to society, the objects of his passions, the external bodies which either pleased or hurt him, would occupy his whole attention. The passions themselves, the desires or aversions, the joys or sorrows, which those objects excited, though of all things the most immediately present to him, could scarce ever be the objects of his thoughts.... Bring him into society, and all his own passions will immediately become the causes of new passions. He will observe that mankind approve of some of them, and are disgusted by others. He will be elevated in the one case, and cast down in the other; his desires and aversions, his joys and sorrows, will now often become the causes of new desires and new aversions, new joys and new sorrows: they will now, therefore, interest him deeply, and often call upon his most attentive consideration.

Our first ideas of personal beauty and deformity, are drawn from the shape and appearance of others, not from our own. We soon become sensible, however, that others exercise the same criticism upon us. We are pleased when they approve of our figure, and are disobliged when they seem to be disgusted. We become anxious to know how far our appearance deserves either their blame or approbation....

In the same manner our first moral criticisms are exercised upon the characters and conduct of other people; and we are all very forward to observe how each of these affects us. But we soon learn, that other people are was no stranger to controversy. But by 1790 he and his followers had much to fear from the reactionary mobs as the French Revolution turned more radical. He was not alone in this regard. Jeremy Bentham, by then notable as an early advocate and advisor to the Revolution, became an ardent defender of the British system and entered a "quiescent" period for most of the decade (see Schofield 2004). Joseph Priestly chose self-exile to the United States (Johnson 2008). As for Smith. in addition to the impact on the revision of TMS, it is likely that the troubles of the time led to his decision during his final says to have his papers destroyed - including whatever was completed of his long promised volume on jurisprudence. 
equally frank with regard to our own. We become anxious to know how far we deserve their censure or applause, and whether to them we must necessarily appear those agreeable or disagreeable creatures which they represent us. We begin, upon this account, to examine our own passions and conduct, and to consider how these must appear to them, by considering how they would appear to us if in their situation. We suppose ourselves the spectators of our own behaviour, and endeavour to imagine what effect it would, in this light, produce upon us. This is the only looking-glass by which we can, in some measure, with the eyes of other people, scrutinize the propriety of our own conduct. If in this view it pleases us, we are tolerably satisfied. We can be more indifferent about the applause, and, in some measure, despise the censure of the world secure that, however misunderstood or misrepresented, we are the natural and proper objects of approbation. On the contrary, if we are doubtful about it, we are often, upon that very account, more anxious to gain their approbation, and, provided we have not already, as they say, shaken hands with infamy, we are altogether distracted at the thoughts of their censure, which then strikes us with double severity.

When I endeavour to examine my own conduct, when I endeavour to pass sentence upon it, and either to approve or condemn it, it is evident that, in all such cases, I divide myself, as it were, into two persons; and that I, the examiner and judge, represent a different character from that other $I$, the person whose con- duct is examined into and judged of. The first is the spectator, whose sentiments with regard to my own conduct I endeavour to enter into, by placing myself in his situation, and by considering how it would appear to me, when seen from that particular point of view. The second is the agent, the person whom I properly call myself, and of whose conduct, under the character of a spectator, I was endeavouring to form some opinion. The first is the judge; the second the person judged of. But that the judge should, in every respect, be the same with the person judged of, is as impossible, as that the cause should, in every respect, be the same with the effect. (TMS, $6^{\text {th }}$ edition, Part III, ch. 1)

There is no explicit mention of an "accountable being" here, but the sense of accountability is clear in the reference to "endeavour" to "examine" and "judge" one's own behavior, and to subject oneself to the spectators.

The argument supporting the contention that the original assertion ("A moral being is an accountable being") is implicit in those and related passages relies, in part, on what we know of Smith's view of rhetoric expressed in his Lectures on Rhetoric and Belles Lettres (hereafter LRBL). In those lectures 
(based on student notes dated 1762), Smith posits a distinction among four different methods for presenting an argument, two "deliberative" and related to persuasion, and two "didacticall" which are intended to "an account of some system". TMS no doubt falls under the didactic form, and it reflects Smith's commitment to an approach he associates with Isaac Newton.

There are two methods in which a didacticall writing containing an account of some system may be delivered; Either 1st we Lay down one or a very few principles by which we explain the severall Rules, or Phaenomena, connecting one with the other in a natural order, or else we beginn with telling that we are to explain such and such things and for each advance a principle either different or the same with those which went before. Virgil in his Georgics follows the latter method; His design is to give us a System of Husbandry; in the 1st he gives us directions for the Cultivation of corn, in the $2 d$ of Trees, in the $3 d$ of Cattle and in the 4th of the Insects called the Bees. If Virgill had begun with enquiring into the pri<n>ciple of vegetation, what was proper to augment it and e contra; In what proportions it was in different soils and what nourishment the different plants required, and putting all these together had directed us what culture and what soil was proper for every different plant, this would have been following the 1st method which is without doubt the most philosophicall one. In the same way in Nat<urall> Phil<osophy> or any other Science of that Sort we may either like Aristotle go over the Different branches in the order they happen to cast up to us, giving a principle commonly a new one for every phaenomenon; or in the manner of Sir Isaac Newton we may lay down certain principles known or proved in the beginning, from whence we account for the severall Phenomena, connecting all together by the same Chain. - This Latter which we may call the Newtonian method is undoubtedly the most Philosophical, and in every scien<c>e $w<h>e t h e r$ of Moralls or Nat<urall> phi<losophy> etc., is vastly more ingenious and for that reason more engaging than the other. It gives us a pleasure to see the phaenomena which we reckoned the most unaccountable all deduced from some principle (commonly a wellknown one) and all united in one chain, far superior to what we feel from the unconnected method where everything is accounted for by itself without any referen[e]ce to the others. (LRBL, Lecture 24; Smith 1983, p. 145)

Taking this perspective into account, one can regard both the $1^{\text {st }}$ edition's "missing" assertion ("A moral being is an accountable being") or the $2^{\text {nd }}$ through $5^{\text {th }}$ editions' missing hypothesis ("Man is considered as a moral, because he is regarded as an accountable being") as implied as the opening statement for the relevant paragraphs in the often cited $6^{\text {th }}$ edition of TMS. 


\section{TMS as Social Theory}

Human society when we contemplate it in a certain abstract and philosophical light, appears like a great, an immense machine - TMS, $6^{\text {th }}$ edition, Part VII, ch. III

The contention that Smith's assertion/hypothesis regarding the centrality of accountable relationships in moral life can be extended to an argument that what he posits is far more than a moral theory. Were TMS published today, it would no doubt be classified as a "social theory" that offers accountable relationships as it basic premise (Campbell 1971; 1981, chapter 5; also Silver 1990). Thus, while few would challenge the claim that Smith's best-known work (WN) marks the founding of modern economics, not all give him his due as a major contributor to modern social theory ( $c f$ Darwall 1999; also Seigel 2005, chapter 5; Ashraf et al 2005).

By all biographic indications, Smith considered TMS his more significant contribution. As well he might, one should add, for in it he articulated a distinctive perspective on social relationships that today stands as a foundational prologue to modern social theory. ${ }^{14}$ It is also clear (although not uncontroversial) that the social theory established in TMS was foundational for the arguments presented in WN published seventeen years later. ${ }^{15}$ Put simply, a careful reading of Smith draws one to conclude that markets (like all other social relationships) are necessarily embedded in moral communities - communities comprised of moral/accountable beings.

At this point it is necessary to clarify the nature of morality as Smith presents it. On its face, Smith's basic premise (expressed in TMS) is simple: our social relationships occur within (are embedded in) the

14 Categorized along with other notable writers of his time as part of the Enlightenment, his views are often mistakenly subsumed under the ideas of "state of nature" and "social contract" (both typically regarded as the salient themes emerging from $17^{\text {th }}$ and $18^{\text {th }}$ century England and France). But Smith's embryonic social psychology provides a different foundation for our understanding of the relationship between individual and collective actions (Khalil 1998, 2005). Along with David Hume, he maintained a connection between behavior and moral agency that Alasdair Maclntyre (1982) claims effectively disappeared with in modern philosophy with the rise of Kantian moral theory.

15 For most the 20th century, Smith scholars engaged in a debate known as the "Adam Smith Problem" that, in essence, raised the question of whether -- and how -- the sympathy-based moral theory of TMS related to the self-interest-based political economy of WN. When conceptualized as such, the two works seemed contradictory rather than complementary or part of a coherent system of thought. By the 1980s the issue was reconceptualized and settled both historically and philosophically. Perhaps the best historical argument comes from what is known of the topical sequence of Smith's lectures during the 1750s. His course involved for sets of lectures on (roughly) religion, moral theory, jurisprudence and political economy. That order obviously speaks to the foundational nature of the moral theory to the political economy, and is supported by his initial plan to follow TMS with a work focused on law (implying that he saw his publication agenda as a coherent sequences based on the lectures). See Buchan 2006, chapter 2. On the philosophical relationship between the two volumes, see Dickey 1986; Werhane 1989; V. Smith 1998; Dwyer 2005. 
context of moral communities. Where Smith differs from other moral theorists of his era is in the assertion that the moral content that defined those communities were, in today's phrasing, "emergent" rather than (1) derivative (from some external or higher authority), (2) generated (through human reasoning), or (3) calculated (on the basis of some basic or overarching principle, e.g. utilitarianism). In contrast to those well-known alternative positions, the "morality" of Smith's moral community has more naturalistic and empirical roots. His approach, as expressed in the paragraphs cited above, can be described as "socially emergent" in the sense that the moral standards we operate under are developed and derived from the very fact of the social relationships of which we are a part (Heath 1995: V. Smith 2003, 2004, 2005). ${ }^{16}$

Put directly, Smith's morality is social. It is manifest in the norms that emerge from interactions between and among individuals (see Seigel 2005, chapter 5), and it is the natural consequence of that interaction that accountability emerges as well. It is important to recognize that Smith's notion of moral accountability is not merely mechanistic; it involves more than being "answerable" or "liable" or otherwise held to account. Those actions and inclinations are merely the outward expressions of what it means to be "accountable" in Smith's sense of the term. Rather, accountability is inherent in the social relationships formed between and among individuals. To restate the point more assertively, Smith's moral being does not merely develop into an accountable being; the moral being is - by definition -an accountable being.

In contrast to the "self-interest" that drives most rational choice models (and with which Smith is often mistakenly associated), ${ }^{17}$ the central psychological mechanism at work inside Smith's moral being is "sympathy," a term that in his hands encompasses a bit more than implied in today's common usage. The term sympathy is typically differentiated from "empathy" in contemporary discussions, but in Smith's case the former is inclusive of the latter, with empathic feelings ("fellow-feelings") more central to his views. Stephen Darwall (2006, pp. 43-48) makes the distinction clearer by noting that the common sense of "sympathy" (more associated with David Hume than Smith) relies on a third-person perspective: I see your plight from my distant viewpoint and I appreciate what you must be going through. What we tend to call empathy ${ }^{18}$ today is central to Smith's sympathetic mechanism, reflects a second-person standpoint: I see your plight from my close relationship to you and I can "simulate" and

16 Cf. the concept of "reflectivity" proffered by George Soros (2008).

${ }^{17}$ For an excellent analysis of the role of the "self" in Smith's work, see Seigel 2005, chapter 5.

${ }^{18}$ The term empathy would not have been part of Smith's vocabulary. OED dates the first English use of "empathy" at 1904, and its technical application to the work of psychologist E. B. Titchener who links it to the German term Einfühlung in a 1909 publication of his lectures on experimental psychology. 
imagine what it must feel like - I can sense and attempt to "feel your pain" (or pleasure, for that matter).

For Smith, social proximity matters. Given close proximity, we form "thick" relationships, ${ }^{19}$ and you are aware of my feelings (or at least can "imagine" those feelings) and appreciate them as if you were I, whether those feelings are of a positive or negative nature. If I feel pride, you can sense that same prideful feeling; if I feel shame, you can sympathetically sense my shame and "imagine" in your own self how I feel. It is this capacity for "fellow feelings" that is at the heart of Smith's theory of moral sentiments, for it provides the natural foundation upon which social relationships are developed. The critical factor is that those very feelings (e.g., of pride, of shame) are themselves rooted in how one perceives the reactions and sentiments of others toward oneself. As highlighted in the quotation provided above, the judgment I apply to my own actions are a reflection of the judgment I believe are being applied to me by the others to whom I relate.

But relationships do vary over space and time, and thick relationships tend to "thin out". The child's sympathetic relationship with parents and siblings is altered by time and circumstance, and new relationships form and change with age. The natural solution is for the individual to adapt to such changes. Socially-derived judgments become organized and internalized in each of us in the form of what Smith called the "impartial spectator" - that part of out consciousness which renders our choices and actions accountable to a moral order of our own (collective) making. It is in that sense that Smith establishes his basic principle that a "moral being is an accountable being."

Here, I contend, is the Smithian foundation for a theory of accountable governance - a theory that embeds governance within moral communities that are formed out of social relationships that are inherently rooted in accountability. From this perspective, accountability is not merely a set of institutionalized mechanisms designed to foster answerability, liability, responsiveness, fidelity, etc. Rather, accountability is an emergent moral order and ethical setting manifested in those implicit and explicit expectations that are part of social life. To speak of "accountable governance" is to focus attention on those social arrangements that provide us with the moral capacity to deal with the wide range of collective action problems faced by all communities.

\section{The Moral Grounding of Market Governance}

Humanity does not desire to be great, but to be beloved. It is not in being rich that truth and justice would rejoice, but in being trusted and believed, recompenses which those virtues must almost always acquire. - TMS, $6^{\text {th }}$ edition, Part III, chapter 5, paragraph 8. 
No doubt, I have crossed an intellectual Rubicon with the assertion that Smith's views on moral accountability can provide a foundation for the development of a theory of governance. I certainly have a long way to travel to develop this into a fully articulated, viable option in the search for such a theory. To make the case for this approach a bit clearer (and perhaps stronger), I will focus on the governance of the domain with which Smith's work is most often associated: markets.

We begin with the assumption that markets - the place where economic exchanges occur within society -- exist at various levels in various forms. Families can be regarded as social arenas within which economic exchanges take place (e.g., Becker 1981), as can that global trade regimes (e.g., Wallach 2002) and all forms of markets between. Markets not only vary in scale and size, but also in content and form. Over the past two years we have become aware of the difference between the financial markets and those associated with traditional manufactures. As any reader of WN can attest, Smith was acutely aware of these variations as well. Throughout WN he notes the differences among national political economies rooted in the level of economic activity, and his critical assessment of various sectors of the economy (see especially Part IV) has aged reasonably well over the last 250 plus years.

What markets also share is a common problem related to how they are governed - that is, how they maintain good order given their particular characteristics. The is the problem central to the classic study of political economy, and it is often lost sight of when we restrict our view of governance to political institutions or fail to realize that any collective social endeavor (including the conduct of market exchanges) requires governance of some sort. As Oliver E. Williamson (1991) points out, economists have long realized - and debated - the existence and appropriateness of "spontaneous and intentional governance" within the economic realm. ${ }^{20}$

For Williamson and others, the examination of alternative governance forms is based on the premise that effective governance arrangements are those that solve the problems of coordinating and controlling the various factors involved in the economic endeavor. Thus, a well-governed market is one where appropriate formal and informal (visible and invisible) mechanisms (e.g., law, contract, trust) are brought to bear on those problems.

\footnotetext{
20 "That we appear to be subject to intentional governance structures everywhere we turn is thus misleading: the real action is largely invisible" (Williamson 1991, p. 159). Williamson also applies the contrast of "visible and invisible governance" in the title of a later paper (1994).
} 
An examination of Smith's WN seems to support the argument that he assumed the same objective for good governance: to facilitate solutions to the problem of coordination and control required to render markets most effective and efficient. Along those lines, Smith's views of a "well-governed society" in regard to markets are clear from the outset (Book I, Ch. 1) in WN:

It is the great multiplication of the productions of all the different arts, in consequence of the division of labour, which occasions, in a well-governed society, that universal opulence which extends itself to the lowest ranks of the people. Every workman has a great quantity of his own work to dispose of beyond what he himself has occasion for; and every other workman being exactly in the same situation, he is enabled to exchange a great quantity of his own goods for a great quantity, or, what comes to the same thing, for the price of a great quantity of theirs. He supplies them abundantly with what they have occasion for, and they accommodate him as amply with what he has occasion for, and a general plenty diffuses itself through all the different ranks of the society.

This view is consistent throughout WN, and it is complemented by Smith's analysis of the basic functions of government found in Books IV and V of that work. However, it would be a mistake to misread this basic message about what constitutes a "well-governed society". It is not merely government or the state that Smith refers to, but rather the governance of society that is to provide its people (i.e., extending to the "lowest ranks) with the "universal opulence" generated by the marketplace - an opulence that "enabled" every workman to partake of the "general plenty" that particular markets are naturally capable of providing.

At this juncture it is necessary to put in perspective the popular vision of Smith as a committed government minimalist or strong advocate for a "laissez faire" approach to the governance of markets. The words that underlie and sustain this view are among the most frequently cited of Smith's words, and they are most often attributed to his published writing:

Little else is required to carry a state to the highest degree of affluence from the lowest barbarism but peace, easy taxes, and a tolerable administration of justice; all the rest being brought about by the natural course of things. All governments which thwart this natural course, which force things into another channel, or which endeavour to arrest the progress of society at a particular point, are unnatural, and, to support themselves, are obliged to be oppressive and tyrannical... 
The passage, often mistakenly assumed to be from WN, is actually found in fragmentary lecture notes (or notes related to a projected volume on political economy) supposedly written by Smith more than two decades before the 1776 publication (i.e., somewhere between 1751 and 1755). The source is his student and first biographer, Dugal Stewart, whose interpretive approach to his subject has been regarded as highly selective and somewhat extreme. ${ }^{21}$ It is unclear whether Smith actually penned those words in a written statement of basic ideas for the future volume, or whether they are a student's attempt at verbatim notes from lectures on political economy that were part of Smith's Glasgow classes during that period. Published by Stewart after his mentor's death, they provide a particularly "laissez faire" spin on Smith's views of government that is not supported by more analytic approach of the published work. Contrary to the mythical view of Smith, WN (while clearly critical of government policy) does not make such a strong assertion on behalf of a minimal government position.

A less often quoted portion of that same fragment from Stewart is more relevant here, and focuses attention not on government per se, but on the way government is used to govern by different public officials:
Man is generally considered by statesmen and projectors as the materials of a sort of political mechanics. Projectors disturb nature in the course of her operations on human affairs, and it requires no more than to leave her alone and give her fair play in the pursuit of her ends that she may establish her own designs...

Here we see - in words attributed to Smith several years before the initial publication of TMS - not merely a critical assessment of government-by- "projectors", but an implied a view of governance (what he would later proffer as a "well-governed society" in WN) as a product of natural development. Governance emerges naturally within "human affairs" if left to its own devices by "statesmen". It is in this context that the basic view of humans as morally accountable beings expressed in the 1759 edition of TMS takes on considerable importance. A "well-governed" market is one in which the natural inclination of "moral beings" to engage in the accountable relationships is facilitated. Good governance in markets, in short, is not merely some arrangement of mechanisms to facilitate coordination and control for the sake of efficient production. Rather, it is found in the existence (and sustainability) of a moral community formed by the relationships among accountable beings. 
Does Smith make an explicit connection between this view of moral accountability and the "wellgoverned" market? Consider the following extended excerpt from TMS ( $6^{\text {th }}$ edition, Part III, chapter 5, paragraph 8):

If we consider the general rules by which external prosperity and adversity are commonly distributed in this life, we shall find, that notwithstanding the disorder in which all things appear to be in this world, yet even here every virtue naturally meets with its proper reward, with the recompense which is most fit to encourage and promote it; and this too so surely, that it requires a very extraordinary concurrence of circumstances entirely to disappoint it. What is the reward most proper for encouraging industry, prudence, and circumspection? Success in every sort of business. And is it possible that in the whole of life these virtues should fail of attaining it? Wealth and external honours are their proper recompense, and the recompense which they can seldom fail of acquiring. What reward is most proper for promoting the practice of truth, justice, and humanity? The confidence, the esteem, and love of those we live with. Humanity does not desire to be great, but to be beloved. It is not in being rich that truth and justice would rejoice, but in being trusted and believed, recompenses which those virtues must almost always acquire.

\section{Concluding "Prologue"}

Twenty-five years ago I became fascinated with the concept of accountability and its role in shaping the decisions and behaviors of policymakers. Initially, I perceived it as having a dual nature. On the one hand, accountability (actually multiple accountabilities) generated "multiple, diverse and often conflicting expectations" that public sector decision makers had to contend with (e.g., see Dubnick \& Romzek, 1993). On the other hand, the various forms of accountability provided a wide range of mechanisms that can be used to manage those expectations.

Convinced of the centrality of accountability in the operations of what is now popularly termed "governance", I began to explore the concept further in an attempt to uncover some basic characteristics of accountability that can be used in the study of "accountable governance". What I found, instead, was conceptual chaos as accountability became increasingly entangled in the political rhetoric of managerialist reform. What was once a somewhat meaningful concept turned out to be promiscuous, attaching itself as a solution to every problem that seemed to emerge from various policy streams. 
At some point in my search for a more meaningful comprehension of accountability and its role in governance I turned to both history and philosophy, and there I found support for the idea that accountability is indeed a core factor - if not the defining factor - in modern governance.

I also became convinced that the requisite foundation for any effective form of accountable governance is the existence of "moral community" (broadly defined) centered on accountable relationships. Without the development of such a moral community in which such relationships have intrinsic value, efforts to generate accountability through instrumental and superficial reforms are bound to fail.

It is in that context that I found the Adam Smith of TMS to be a pivotal figure. Attracted initially by the single sentence that provides the focus of this paper, I have become convinced that in Smith's ethical theories we have the foundations for a theory of accountable governance ${ }^{22}$ which I believe is necessary for advancing the study of modern governance in general.

There is obviously much more to be done to make the case for this view - and to put it to use.... 


\section{References:}

Ashraf, Nava, Colin F. Camerer, and George Loewenstein. 2005. Adam Smith, Behavioral Economist. JOURNAL OF ECONOMIC PERSPECTIVES 19 (3):131-145.

Becker, Gary S. 1981. A TREATISE ON THE FAMILY. Cambridge: Harvard University Press.

Brown, Vivienne. 1994. ADAM SMITH'S DISCOURSE: CANONICITY, COMMERCE, AND CONSCIENCE. London: Routledge.

- - . 1997. "Mere Inventions of the Imagination": A Survey of Recent Literature on Adam Smith. ECONOMICS AND PHILOSOPHY 13 (2):281-312.

Buchan, James. 2006. THE AUTHENTIC ADAM SMITH: HIS LIFE AND IDEAS. New York: W.W. Norton.

Campbell, Tom. 1971. ADAM SMITH'S SCIENCE OF MORALS. London,: Allen and Unwin.

- - . 1981. SEVEN THEORIES OF HUMAN SOCIETY. Oxford: Oxford University Press.

Cannan, Edwin. 1904. Editor's Introduction. In AN INQUIRY INTO THE NATURE AND CAUSES OF THE WEALTH OF NATIONS, edited by E. Cannan. London,: Methuen \& co.

Darwall, Stephen. 1999. Sympathetic Liberalism: Recent Work on Adam Smith. PHILOSOPHY AND PUBLIC AFFAIRS $28(2): 139-164$.

Darwall, Stephen L. 2006. THE SECOND-PERSON STANDPOINT: MORALITY, RESPECT, AND ACCOUNTABILITY. Cambridge, MA: Harvard University Press.

Dickey, Laurence. 1986. Historicizing the "Adam Smith Problem": Conceptual, Historiographical, and Textual Issues. JOURNAL OF MODERN HISTORY 58 (3):580-609.

Dubnick, Melvin, and Ciarán O'Kelly. 2005. Accountability Through Thick and Thin: Making Assessments and Making Cases. In ETHICS IN PUBLIC MANAGEMENT, edited by H. G. Frederickson and R. K. Ghere. Armonk, NY: M. E. Sharpe.

- - , and Barbara S. Romzek. 1993. Accountability and the Centrality of Expectations in American Public Administration. In RESEARCH IN PUBLIC ADMINISTRATION, edited by J. L. Perry. Greenwich CT: JAI PRESS.

Dwyer, John. 2005. Ethics and Economics: Bridging Adam Smith's Theory of Moral Sentiments and Wealth of Nations. JOURNAL OF BRITISH STUDIES 44 (4):662-687.

Evensky, Jerry. 2001. Adam Smith's Lost Legacy. Southern Economic Journal 67 (3):497-517.

- - . 2005. ADAM SMITH'S MORAL PHILOSOPHY: A HISTORICAL AND CONTEMPORARY PERSPECTIVE ON MARKETS, LAW, ETHICS, AND CULTURE. New York, NY: Cambridge University Press.

Griswold, Charles L. 1999. ADAM SMITH AND THE VIRTUES OF ENLIGHTENMENT. New York: Cambridge University Press.

Heath, Eugene. 1995. The Commerce of Sympathy: Adam Smith on the Emergence of Morals. JOURNAL OF THE HISTORY OF PHILOSOPHY 33 (3):447-466. 
Dubnick, "A moral being is an accountable being", 21 April 2010

Johnson, Steven. 2008. The invention of air : a story of science, faith, revolution, and the birth of America. New York: Riverhead Books.

Kennedy, Gavin. 2005. ADAM SMITH'S LOST LEGACY. New York: Palgrave Macmillan.

Khalil, Elias. 1998. Is Justice the Primary Feature of the State? Adam Smith's Critique of Social Contract Theory. EUROPEAN JOURNAL OF LAW AND ECONOMICS 6 (3):215-230.

Khalil, Elias L. 2005. An anatomy of authority: Adam Smith as political theorist. CAMBRIDGE JOURNAL OF ECONOMICS 29 (1):57-71.

Levi, Margaret. 2006. Presidential Address: Why We Need a New Theory of Government. PERSPECTIVES ON POLITICS 4 (1): 5-19

Macfie, A. L. 1961. Adam Smith's Theory Of Moral Sentiments. SCOTTISH JOURNAL OF POLITICAL ECONOMY 8 (1):12-27.

Macintyre, Alasdair. 1982. How moral agents became ghosts or why the history of ethics diverged from that of the philosophy of mind. SYNTHESE 53 (2):295-312.

Margalit, Avishai. 2002. THE ETHICS OF MEMORY. Cambridge, Mass.: Harvard University Press.

Mill, John Stuart. 1909. PRINCIPLES OF POLITICAL ECONOMY, WITH SOME OF THEIR APPLICATIONS TO SOCIAL PHILOSOPHY. Edited by W. J. Ashley. London: Longmans, Green, and Co.

Nussbaum, Martha Craven. 2006. FRONTIERS OF JUSTICE: DISABILITY, NATIONALITY, SPECIES MEMBERSHIP. Cambridge, Mass.: The Belknap Press : Harvard University Press.

Rae, John. 1895. LIFE OF ADAM SMITH. London: Macmillan \& Co.

Raphael, D. D. 2007. THE IMPARTIAL SPECTATOR: ADAM SMITH'S MORAL PHILOSOPHY. New York: Oxford University Press.

Recktenwald, Horst Claus. 1978. An Adam Smith Renaissance Anno 1976? The Bicentenary Output-A Reappraisal of his Scholarship. Journal of Economic Literature 16 (1):56-83.

Rothschild, Emma. 1992. Adam Smith and Conservative Economics. THE ECONOMIC HISTORY REVIEW 45 (1):74-96.

---. 2001. ECONOMIC SENTIMENTS: ADAM SMITH, CONDORCET, AND THE ENLIGHTENMENT. Cambridge, MA: Harvard University Press.

Samuelson, Paul A. 1977. A Modern Theorist's Vindication of Adam Smith. The American Economic Review 67 (1):42-49.

Schofield, Philip. 2004. Jeremy Bentham, the French Revolution and political radicalism. History of European Ideas 30 (4):381-401.

Seigel, Jerrold E. 2005. THE IDEA OF THE SELF: THOUGHT AND EXPERIENCE IN WESTERN EUROPE SINCE THE SEVENTEENTH CENTURY. New York: Cambridge University Press.

Sen, Amartya. 2009. THE IDEA OF JUSTICE. Cambridge, Mass.: Belknap Press of Harvard University Press.

-- . 2010. Adam Smith and the Contemporary World. ERASMUS JOURNAL FOR PHILOSOPHY AND ECONOMICS 3 
(1):50-67.

Silver, Allan. 1990. Friendship in Commercial Society: Eighteenth-Century Social Theory and Modern Sociology. AMERICAN JOURNAL OF SOCIOLOGY 95 (6):1474-1504.

Simon, Herbert A. 1947. ADMINISTRATIVE BEHAVIOR. New York,: Macmillan Co.

--—. 1957. ADMINISTRATIVE BEHAVIOR: A STUDY OF DECISION-MAKING PROCESSES IN ADMINISTRATIVE ORGANIZATION, 2nd edition. New York: Free Press.

Smith, Adam. 1759. THE THEORY OF MORAL SENTIMENTS. 1st ed. London: A. Millar.

-- . 1761. THE THEORY OF MORAL SENTIMENTS. 2nd ed. London: A. Millar.

---. 1976. THE THEORY OF MORAL SENTIMENTS. Edited by D. D. Raphael and A. L. Macfie. 6th ed, The Glasgow edition of the works and correspondence of Adam Smith. Oxford: Oxford University Press.

-- - 1983. LECTURES ON RHETORIC AND BELLES LETTRES. Edited by J. C. Bryce, The Glasgow edition of the works and correspondence of Adam Smith. Oxford: Oxford University Press.

---. 1987. THE CORRESPONDENCE OF ADAM SMITH. Edited by E. C. Mossner and I. S. Ross. 2nd ed, The Glasgow edition of the works and correspondence of Adam Smith. Oxford: Oxford University Press.

Smith, Vernon L. 1998. The Two Faces of Adam Smith. SOUTHERN ECONOMIC JOURNAL 65 (1):2-19.

---. 2003. Constructivist and Ecological Rationality in Economics. AMERICAN ECONOMIC REVIEW 93 (3):465508.

---. 2004. Human nature: an economic perspective. DAEDALUS 133 (4):67-76.

- - . 2005. Behavioral economics research and the foundations of economics. JOURNAL OF SOCIO-ECONOMICS $34(2): 135-150$.

Soros, George. 2008. THE NEW PARADIGM FOR FINANCIAL MARKETS: THE CREDIT CRISIS OF 2008 AND WHAT IT MEANS. New York: PublicAffairs.

Sweezey, Paul M. 1942. THE THEORY OF CAPITALIST DEVELOPMENT. New York: Modern Reader.

Wallach, Lori M. 2002. Accountable Governance in the Era of Globalization: The WTO, NAFTA, and International Harmonization of Standards. UNIVERSITY OF KANSAS LAW REVIEW 50 (4):823-866.

Walzer, Michael. 1994. THICK AND THIN: MORAL ARGUMENT AT HOME AND ABROAD. Notre Dame: University of Notre Dame Press.

Werhane, Patricia H. 1989. The Role of Self-Interest in Adam Smith's Wealth of Nations. JOURNAL OF PHILOSOPHY 86 (11):669-680.

Wildavsky, Aaron. 1979. THE POLITICS OF THE BUDGETARY PROCESS. 3rd ed. Boston, MA: Little Brown.

---. 1988. THE NEW POLITICS OF THE BUDGETARY PROCESS. Glenview, IL: Scott Foresman.

Wilson, James Q. 1993. THE MORAL SENSE. New York: Free Press. 